\title{
IDENTIFIKASI JALUR PEJALAN KAKI DI KAWASAN WATERFRONT, SENG HIE, PONTIANAK
}

\author{
GULTOM, Bontor Jumaylinda \\ Email: bontor_arch@yahoo.com
}

\begin{abstract}
ABSTRAK
Kota yang terletak pada kondisi geografis berada pada tepian sungai, sebaiknya menggunakan prinsip waterfront dalam perancangan kotanya. Salah satu prinsip waterfront adalah terdapat akses untuk memudahkan manusia berhubungan dengan air. Belakangan ini, terjadi kecenderungan mulai ditinggalkannya transportasi sungai dan beralih ke transportasi darat yang memastikan bahwa hubungan manusia dengan air akan semakin berkurang. Seng Hie sebagai salah satu kawasan waterfront di Pontianak, merupakan daerah yang memungkinkan publik untuk berhubungan langsung dengan air. Apakah di Seng Hie masih terdapat jalur pejalan kaki yang dapat memberi citra kawasan waterfront? Pertanyaaan ini dapat dijawab dengan melakukan penelitian dengan mengidentifikasi jalur pajalan kaki yang berada di kawasan waterfront, Seng Hie. Metode penelitian yang digunakan adalah rasionalistik kualitatif. Menggunakan metode deskriptif dan evaluative berdasarkan parameter teori. Penelitian dilakukan pada kawasan dengan membagi kawasan menjadi 4 (empat) penggal, berdasarkan kondisi eksisting terdapatnya akses yang membagi kawasan. Lingkup penelitian merupakan batasan terhadap keberadaan dan jenis jalur pejalan kaki. Pada kawasan Seng Hie masih ditemukan tersedianya jalur pejalan kaki, dengan 5 (lima) jenis jalur pejalan kaki. Terdapat permasalahan umum pada keseluruhan kawasan, yaitu: tidak terdapat kesinambungan hubungan seluruh jalur pejalan kaki, jalur pejalan kaki tidak dapat memberi kenyamanan bagi publik untuk berhubungan langsung dengan air, jalur pejalan kaki tidak memberi keleluasaan publik untuk menikmati pemandangan sungai, dan dermaga tidak dapat menampung kegiatan komersial yang melayani kegiatan rekreasi. Hasil penelitian tersebut dapat disimpulkan bahwa kawasan Seng Hie tidak menyediakan jalur pejalan kaki yang sesuai dengan prinsip waterfront.
\end{abstract}

Kata kunci: Identifikasi, jalur pejalan kaki, kawasan waterfront.

\begin{abstract}
City that located in the edge of the river should apply waterfront principle in the design of the city. One of the waterfront principle is there is an access that able to make human associated with water easily. Lately, people have tendency to leave the water transportation and move to ground transportation that it means that the relation of human and water is diminished. Seng hie as one of the waterfront region in Pontianak, is an area that able to make a direst association between human and the water. Is Seng hie have a pedestrian track that can give an image of the waterfront area? This question can be answered with doing an identification of pedestrian track that exist in waterfront region, seng hie. The method that used is qualitative rationalistic. And also use descriptive and evaluative methods based on theory as the parameter. The study was conducted in the region by dividing them into 4 sections, based on the existence of the access that divides the area. The scope of the research is the limitation of the existence and the kind of the pedestrian track. In Seng hie's area still found the pedestrian track, with 5 kinds of the track. There are some common problem, in the whole of the region, there are: there is no synchronization of the relationship in all of the pedestrian track, the pedestrian track is not able to give a comfort situation or feeling to be associated with water, the pedestrian track is not able to allow the pedestrian to enjoy the river view and also the docks cannot accommodate the commercial activity that serve the recreational activity. By the result of the study, we can conclude that seng hie area is not giving a pedestrian track that accordance with the waterfront principle.
\end{abstract}

Keywords: Identification, pedestrian track, waterfront city.

\section{PENDAHULUAN}

Bentuk tanggapan perancangan kawasan terhadap potensi kondisi geografis sebuah kawasan kota yang bertipikal kota air adalah perancangan kawasan berbasis waterfront. Kawasan waterfront memiliki prinsip yang sebaiknya memperhatikan hal-hal ber- ikut (Francisco, 1997; 18): (1) menampilkan karakter kawasan waterfront; (2) bangunan di sekitar kawasan berorientasi ke air; (3) menampilkan aktifitas keairan sebagai aktifitas utama; (4) terdapat akses menuju dan dari daerah waterfront yang aman, nyaman dan memudahkan manusia berhubungan dengan air. Air sebagai wadah utama dalam setiap aktifitas masya- 
rakatnya, sehingga dalam hubungannya dengan melayani kebutuhan masyarakat, air selalu dekat dan dapat diakses dan diperlukan sarana untuk memfasilitasi hubungan tersebut berupa jalur pejalan kaki.

Menurut Sirvani $(1985 ; 31)$ salah satu elemen penting dalam perancangan kota adalah jalur pejalan kaki. Jalur pejalan kaki yang baik dapat memiliki kejelasan, nyaman dan mudah diakses serta memberikan rasa aman bagi para penggunanya. Jalur yang memenuhi kriteria tersebut berarti berhasil menciptakan ruang yang manusiawi.

Jacobs (1995;269-292) mengemukakan bahwa sebuah jalur atau jalan yang berhasil memenuhi kriteria perancangan sebagai berikut: (1) jalan dapat diakses dan mudah ditemukan; (2) aman dan nyaman secara fisik; (3) partisipatif; (4) menimbulkan kenangan; dan (5) representatif. Penciptaan sebuah jalur pejalan kaki yang menimbulkan kesan positif para penggunanya (Gultom, 2006; 61), tidak hanya mencakup ada atau tidaknya jalur untuk diakses.

Penelitian identifikasi jalur pejalan kaki pada kawasan Seng hie perlu dilakukan untuk melihat kejelasan, nyaman dan mudah diakses serta memberikan rasa aman bagi para penggunanya. Tujuannya untuk membuktikan apakah Seng Hie sebagai salah satu daerah waterfront di Pontianak masih menerapkan prinsip waterfront, yaitu dengan menyediakan jalur pejalan kaki sebagai sarana untuk berhubungan dengan air.

\section{METODE PENELITIAN}

Penelitian ini menggunakan pendekatan rasionalistik. Menggunakan metode deskriptif kualitatif. Lingkup enelitian merupakan batasan terhadap ke- beradaan dan jenis jalur pejalan kaki. Wilayah penelitian ditetapkan berdasarkan pertimbangan akan kawasan yang memiliki sejarah tempat aktifitas masyarakat yang berhubungan dengan air.

Lokasi penelitian dibagi menjadi 4 (empat) penggalan. Setiap penggalan dianalisa dimensi jalur pejalan kaki. Keberadaan dan dimensi pejalan kaki yang terletak di bagian depan bangunan mengidentifikasi apakah Pontianak masih menerapkan prinsip waterfront, yaitu dengan menyediakan jalur pejalan kaki sebagai sarana untuk berhubungan dengan air

Adapun tahap penelitian yang dilakukan sebagai berikut:

1. Persiapan Mencari Data

2. Pengumpulan Data lapangan (Observasi)

a) Pembagian daerah amatan penelitian dilakukan karena terdapat 3 akses yang membagi kawasan menjadi 4 penggalan

b) Pengumpulan data dilakukan dengan mendata

- Penggal yang memiliki jalur pejalan kaki dan yang tidak

- Penggal yang memiliki jalur pejalan kaki dan dermaga

- Penggal yang memiliki kekhususan tertentu

3. Proses Analisis

Proses analisis menggunakan metode deskriptif dengan melihat keberadaan jalur pejalan kaki.

Tahapan penelitian dilakukan dengan mengidentifikasi keberadaan jalur pejalan kaki pada setiap penggalan pada kawasan. Parameter jalur pejalan kaki menggunakan dimensi jalur pejalan kaki yang terbagi atas 4 (empat) kategori, yaitu:

1. Tidak terdapat jalur pejalan kaki

2. $0-1,5$ meter, mengidentifikasi jalur pejalan kaki yang dapat dilewati 2-3 orang

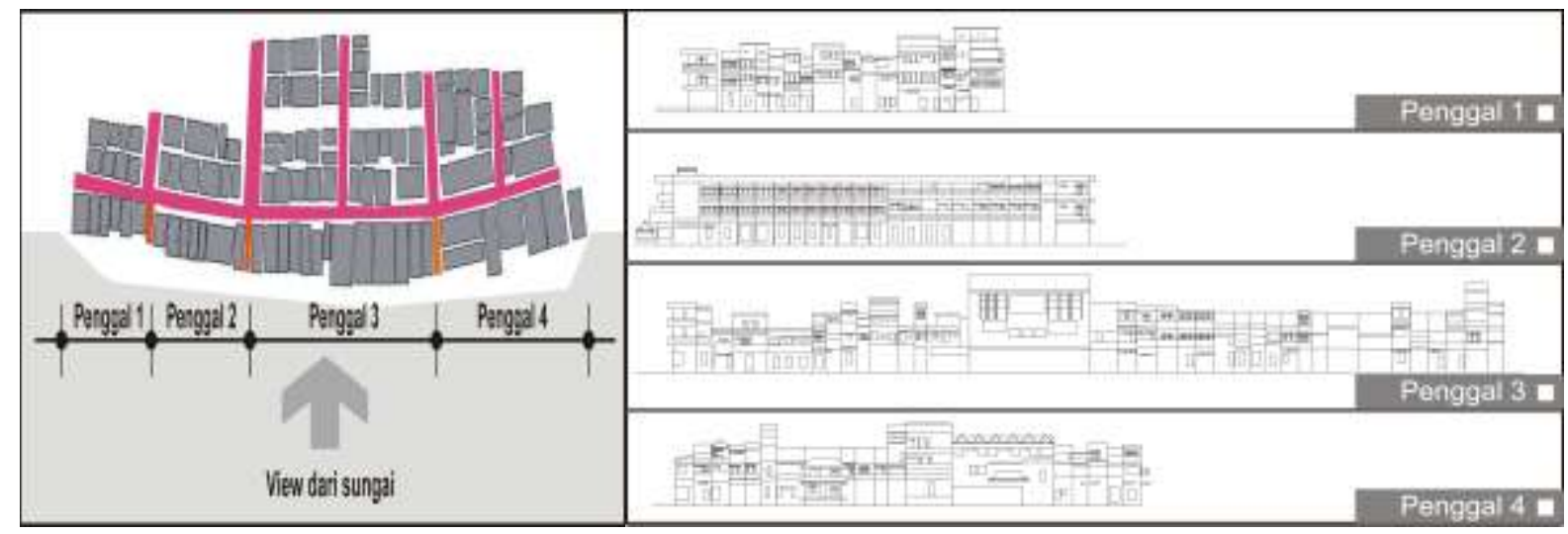

Gambar 1. Pembagian dan Gambar Tiap Penggalan 
3. 1,5-4 meter, mengidentifikasi jalur pejalan kaki yang dapat dilewati lebih dari 5 orang

4. Lebih dari 4 meter, mengidentifikasi jalur pejalan kaki yang dapat dilewati lebih dari 5 orang dan dapat berfungsi sebagai open space.

Temuan pada penelitian ini dimaksudkan untuk mengidentifikasi ada atau tidak adanya jalur pejalan kaki pada kawasan ini, dan ditemukan jenis jalur pejalan kaki yang terdapat pada kawasan Seng Hie. Hasil penelitian akan memberikan kesimpulan apakah kawasa Seg Hie masih menerapkan prinsip waterfront.

\section{HASIL DAN PEMBAHASAN}

Menurut Francisco (1997; 20), pada kawasan waterfront yang baik menyediakan akses publik dan open space. Akses dan open space berfungsi sebagai tempat melihat pemandangan, dan berfungsi juga untuk kontrol publik terhadap daerah air. Pemandangan di kawasan waterfront dapat berupa pemandangan tepi air, aktifitas waterfront, pemandangan sepanjang jalan tepi air, pemandangan latar belakang waterfront, pemandangan dari tempat tinggi.

Kualitas daerah waterfront dapat terjaga apabila akses publik dan open space memperhatikan konektifitas ke air, konektifitas ke promenade, menunjukkan identitas air, memiliki fasilitas ruang terbuka untuk publik, tanggap terhadap iklim, terdapat fasilitas publik, menampung kegiatan komersial yang melayani kegiatan rekreasi, memberi keamanan dan kenyamanan, dan kejelasan memandang ke segala arah serta dilengkapi dengan material yang mendukung iklim setempat. Dan pada kawasan Seng Hie, akses publik diwakili oleh jalur pejalan kaki dan open space diwakili dengan dermaga.

Pada penggal 1 (lihat gambar 2), tidak terdapat jalur pejalan kaki yang menghubungkan keseluruhan bangunan pada penggal ini. Terdapat beberapa bangunan yang memiliki dermaga, dan keberadaan dermaga tersebut tidak dapat diakses oleh publik. Hal ini terlihat dari bentuk dermaga yang hanya dapat dilalui dari bangunan tersebut saja, dan tidak dapat dilalui dari bangunan-bangunan lain walaupun masih dalam satu penggal. Hal ini menyebabkan air tidak

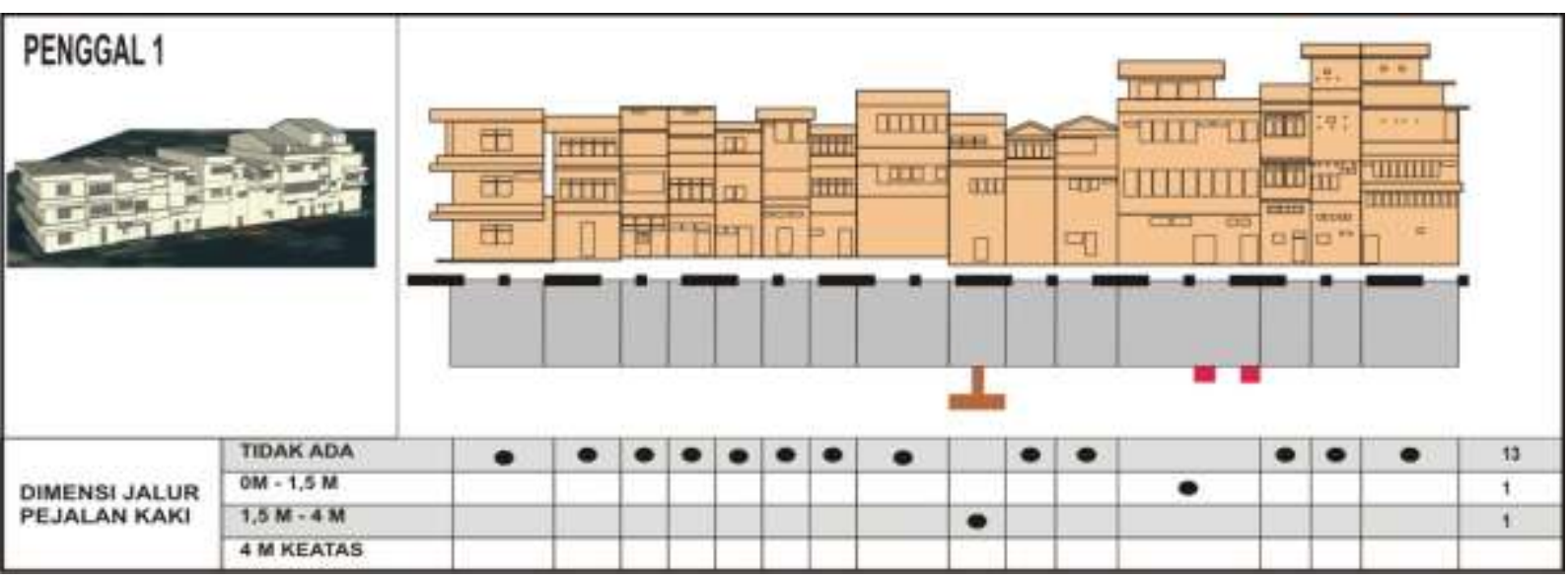

Gambar 2. Penggal 1

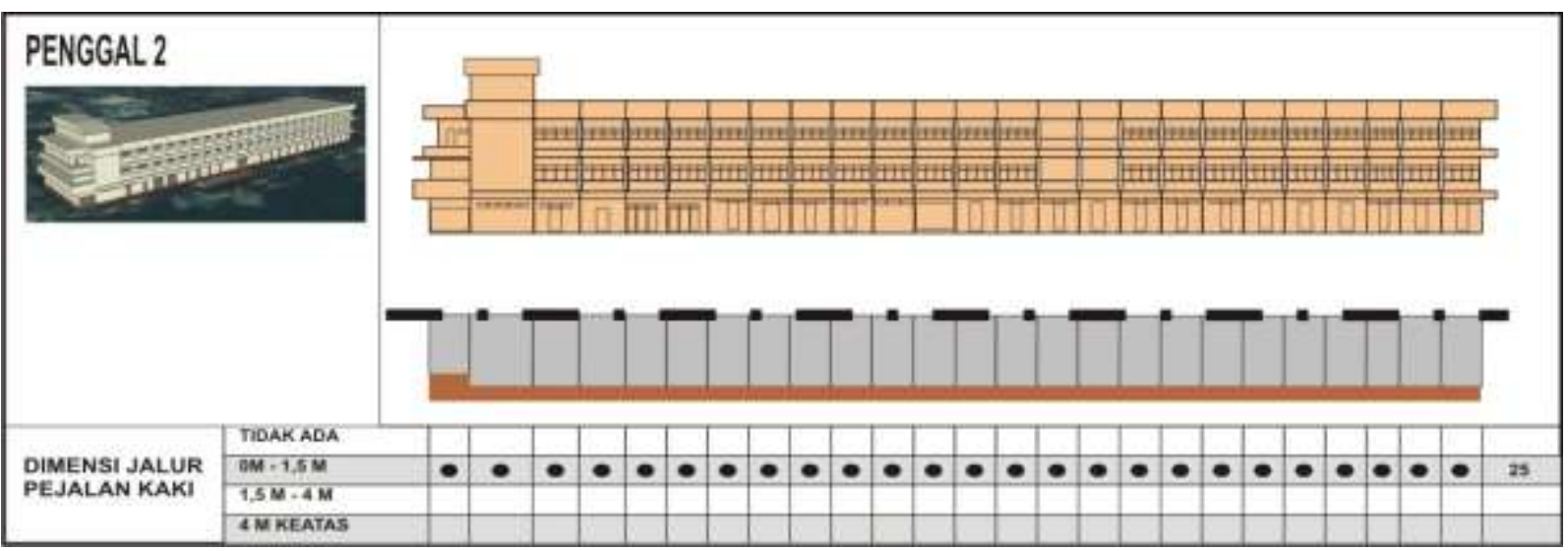

Gambar 3. Penggal 2 
dapat diakses dengan leluasa oleh publik karena air hanya bisa dicapai melalui dermaga yang tidak dihubungkan dengan jalur pejalan kaki.

Pada penggal 1, konektifitas dengan air sangat kecil, sehingga identitas sebagai kawasan waterfront tidak terlihat. Tidak terdapat fasilitas ruang terbuka untuk publik dan tidak bisa memandang daerah waterfront dengan leluasa. Tidak terdapat fasilitas untuk publik yang aman dan nyaman, sehingga tidak dapat menampung kegiatan rekreasi.

Pada penggal 2 (lihat gambar 3), tidak terdapat dermaga namun terdapat jalur pejalan kaki pada semua bangunan. Jalur pejalan kaki pada penggal ini memiliki dimensi ukuran yang sama yaitu 1,5 meter. Air dapat diakses dengan mudah oleh publik. Pada jalur pejalan kaki yang ada hanya bisa digunakan untuk sirkulasi dan tidak bisa digunakan untuk kegiatan publik yang memungkinkan untuk berhubungan langsung dengan air.

Pada penggal 2, terdapat jalur pejalan kaki untuk konektifitas dengan air, namun dimensi jalur pejalan kaki tidak mencukupi untuk menikmati pemandangan waterfront dengan leluasa. Tidak terdapat fasilitas ruang terbuka seperti dermaga dan fasilitas publik yang aman dan nyaman, sehingga tidak dapat menampung kegiatan rekreasi.
Pada penggal 3 (lihat gambar 4), terdapat jalur pejalan kaki pada semua bangunan dan hanya terdapat satu dermaga pada bangunan yang berada di tengah bangunan. Jalur pejalan kaki yang tersedia berdimensi berbeda disebabkan maju mundur bangunan yang tidak sama. Jalur pejalan kaki yang berada pada pengal bangunan tidak berhubungan langsung dengan dermaga, karena berada di belakang dermaga dan dihalangi dengan majunya bangunan berdermaga tersebut. Dermaga tersebut berdimensi besar namun hanya melayani kebutuhan satu bangunan saja dan hanya dapat dilalui oleh bangunan tersebut. Secara keseluruhan air tidak dapat diakses dengan leluasa oleh publik, karena air hanya bisa dicapai secara terpisah-pisah. Apabila melalui dermaga tidak dapat mengakses jalur pejalan kaki dan sebaliknya, apabila melalui jalur pejalan kaki tidak dapat mengakses dermaga.

Pada penggal 3, terdapat jalur pejalan kaki dan dermaga yang menunjukkan identitas air. Jalur yang terhubung namun tidak berkesinambungan, menyebabkan konektifitas ke air menjadi terhambat sehingga tidak menimbulkan rasa aman dan nyaman. Dermaga sebagai ruang terbuka berdimensi besar, menyebabkan pemandangan dapat dinikmati dengan leluasa, namun tidak dapat diakses dari berbagai arah,

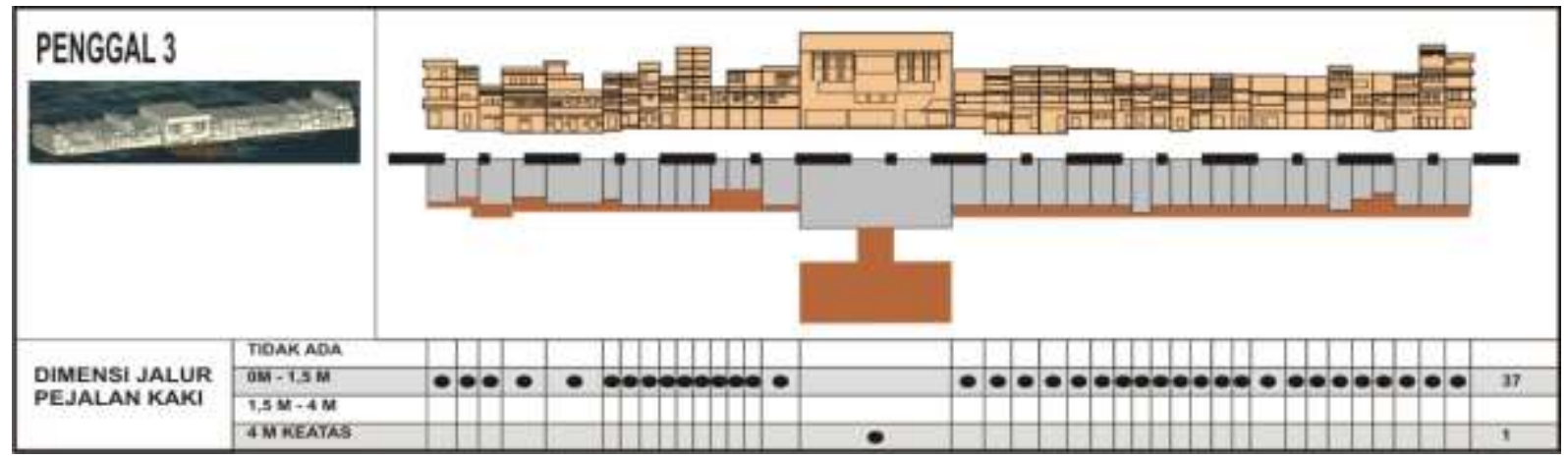

Gambar 4. Penggal 3

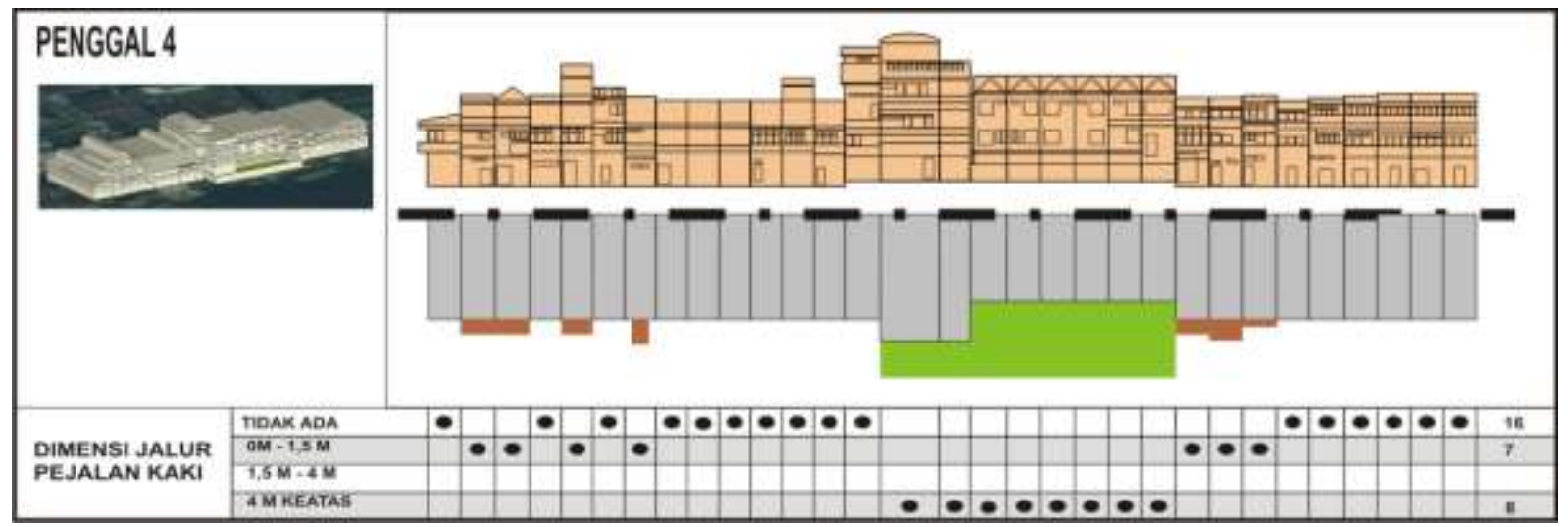

Gambar 5. Penggal 4 
sehingga tidak dapat melayani kegiatan rekreasi secara keseluruhan.

Pada penggal 4 (lihat gambar 5), tidak terdapat jalur pejalan kaki yang menghubungkan keseluruhan bangunan dan terdapat beberapa bangunan yang memiliki dermaga dengan bentuk dan dimensi yang berbeda-beda. Pada bagian tengah penggal 4 terdapat beberapa bangunan yang membuat open space yang hanya dapat melayani bangunan dibelakangnya, namun tidak dapat diakses dari bangunan lain karena ditutupi oleh pagar tinggi. Air tidak dapat diakses dengan leluasa oleh publik karena air hanya bisa dicapai melalui dermaga-dermaga dan tidak terdapat jalur pejalan kaki yang menghubungkan keseluruhan penggal 4 ini.

Pada penggal 4, konektifitas dengan air sangat kecil. Identitas air juga tidak diperlihatkan karena dermaga sebagai wadah penampung kegiatan keairan tidak ada. Ruang terbuka yang ada, tidak diperuntukkan untuk publik sehingga tidak dapat menampung kegiatan komersial yang melayani kegiatan rekreasi.

Secara keseluruhan pada kawasan Seng Hie, ditemukan 5 (lima) jenis jalur pejalan kaki, yaitu dapat di identifikasi sebagai berikut:

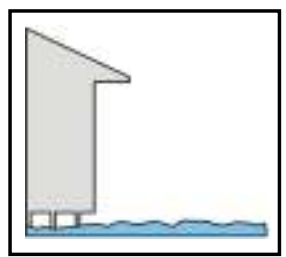

1). Bangunan tanpa jalur pejalan kaki, yaitu apabila tidak ditemukan jalur pejalan kaki yang menghubungkan satu bangunan dengan bangunan lain di dalam satu penggal. Bangunan tanpa jalur pejalan kaki ini terdapat pada Penggal 1 dan Penggal 4.

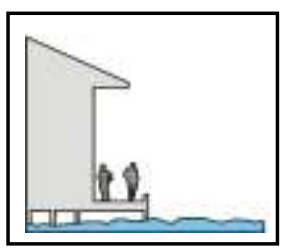

2). Bangunan dengan jalur pejalan kaki namun jalur tersebut tidak saling berhubungan satu sama lain. Bangunan dengan jalur pejalan kaki terdapat pada Penggal 2 dan Penggal 3.

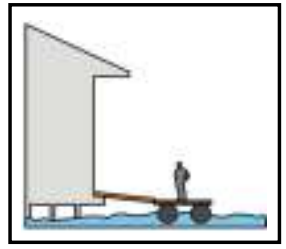

3). Bangunan dengan dermaga, yaitu bangunan yang menyediakan dermaga untuk melayani kegiatan pada bangunan tersebut. Bangunan dengan dermaga terdapat pada Penggal 1, Penggal 3 dan Penggal 4.

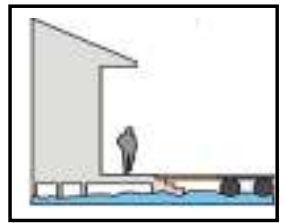

). Bangunan dengan dermaga dan jalur pejalan kaki, yaitu bangunan yang memiliki jalur pejalan kaki sekaligus menyediakan dermaga. Ba- ngunan dengan dermaga dan jalur pejalan kaki terdapat pada Penggal 3.

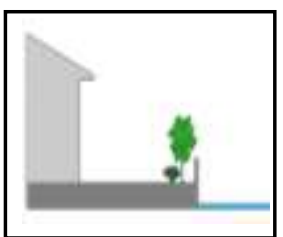

5). Bangunan dengan ruang luar yaitu bangunan yang ditemukan memiliki ruang luar. Bangunan dengan ruang luar terdapat pada Penggal 4.

Seng Hie sebagai salah satu kawasan waterfront di Pontianak masih menyediakan jalur pejalan kaki dan dermaga sebagai salah satu ciri kawasan waterfront. Kawasan Seng Hie terdapat dermaga dengan dimensi yang variatif, dan terletak pada bagian-bagian tertentu pada kawasan. Dermaga digunakan untuk konektifitas ke air. Dermaga tersebar secara tidak merata, hanya melayani kegiatan pada bangunan yang berada di belakangnya, sehingga tidak berfungsi sebagai fasilitas ruang terbuka untuk publik.

Dermaga tidak menghubungkan semua jalur pejalan kaki yang berada di kawasan. Kesinambungan kegiatan dalam mengontrol air menjadi terhambat. Dermaga tidak bisa menampung kegiatan komersial yang melayani kegiatan rekreasi pada keseluruhan kawasan, karena tersedia bagi bangunan yang membutuhkan dermaga untuk pendukung kegiatannya.

Jalur pejalan kaki sebagai akses yang memungkinkan publik untuk berhubungan langsung dengan air, tidak tersebar secara merata. Bahkan terdapat jalur pejalan kaki yang terpenggal secara fisik sehingga tidak dapat diakses dengan mudah dan publik tidak dapat menikmati pemandangan air dari keseluruhan titik pada kawasan Seng Hie.

Pada sebagian penggal kawasan, jalur pejalan kaki terbentuk dari maju mundur bangunan, sehingga jalur pejalan kaki menjadi tidak teratur dan memiliki ritme yang menghasilkan pola tertentu dan tidak membosankan. Jalur pejalan kaki pada kawasan ini tidak dilengkapi dengan fasilitas publik seperti tempat memancing sebagai kegiatan rekreasi khas daerah waterfront.

\section{KESIMPULAN}

Terdapat permasalahan umum pada keseluruhan kawasan, yaitu: tidak terdapat kesinambungan hubungan seluruh jalur pejalan kaki, jalur pejalan kaki tidak dapat memberi kenyamanan bagi publik untuk berhubungan langsung dengan air, jalur pejalan kaki tidak memberi keleluasaan publik untuk menikmati pemandangan sungai, dan dermaga tidak dapat menampung kegiatan komersial yang melayani kegiatan rekreasi. Hasil penelitian tersebut dapat 
disimpulkan bahwa kawasan Seng Hie tidak menyediakan jalur pejalan kaki yang sesuai dengan prinsip waterfront.

Adapun saran dan rekomendasikan pada pengembangan kawasan ini agar menyelaraskan dengan prinsip waterfront yaitu sebagai berikut:

- Kawasan waterfront yang baik meyediakan jalur pejalan kaki sebagai wadah untuk kontrol publik akan air.

- Jalur pejalan kaki Menghubungkan setiap wilayah dengan mudah.Jalur pejalan kaki yang baik dapat dilewati oleh publik dalam intensitas besar kerena merupakan milik publik untuk melayani kegiatan rekreasi air seperti berlayar dan memancing.

- Jalur pejalan kaki didesain dengan menampilkan keamanan dan kenyamanan bagi publik. Jalur pejalan kaki yang baik memungkinkan publik untuk menikmati pemandangan keseluruh kawasan waterfront.

- Kawasan waterfront yang baik menyediakan Open space dan dapat berupa dermaga.
- Dermaga sebaiknya tidak hanya melayani kegiatan pelayaran tetapi juga melayani kegiatan rekreasi untuk publik, sehingga dasainnya harus terdapat hubungan langsung dengan jalur pejalan kaki.

- Dermaga sebaiknya disediakan secara merata pada keseluruhan kawasan untuk pemerataan akses dari arah sungai.

- Ruang luar yang terdapat pada sebagian bangunan sebaiknya dibuka dan dapat di akses oleh publik dengan leluasa.

\section{DAFTAR PUSTAKA}

Francisco, S. (1997). Waterfront Design and Access. Gultom, B.J. (2006). Master Thesis, Kualitas Visual Fasad Bangunan Kawasan Waterfront, Seng Hie, Pontianak, Kalimantan Barat, Universitas Gadjah Mada.

Jacobs, A. B. (1995). Great Street, MIT Press, Cambridge, Massachusetts.

Sirvani, H. (1985). The Urban Design And Process, Van Nostrand Reinhold Company. 